\title{
Az íntranszplantáció alkalmazása a kéz hajlítóín sérüléseinek ellátásában Világirodalmi áttekintés
}

\author{
DR. BÍRÓ VILMOS
}

\section{ÖSSZEFOGLALÁS}

Napjainkban a primer ínhelyreállítás térhódítása következtében az íntranszplantátumok alkalmazásának jelentősége csökkent, azonban még ma is fontos eljárás maradt a szekunder rekonstrukciók eseteiben. A szerző a dolgozatban a világirodalmi adatok tükrében tárgyalja a graftok felhasználásának történeti előzményeit, a jelenlegi, modern ismeretanyagot és áttekinti a különböző helyreállító sebészi eljárásokat. Végül ismerteti a jelenlegi és a jövőben várható fontosabb elképzeléseket: a csúszófelszín kialakítást, az érnyeles ínáthelyezést, továbbá az allograftokkal végzett, valamint a biomateriális és sejt-alapú (cell-based) kezeléseket. A dolgozat végéhez a szerző az érdeklődő olvasó számára bőséges irodalomjegyzéket csatolt.

Kulcsszavak: Íntranszplantáció; Hajlitóín; Ínsérülések; Kézsérülések; Ujjsérülések; Szövetépités; Tissue engineering;

V. Biró: The use of tendon transplantation in the treatment of injured hand flexor tendons. A review of the literature

Nowadays the importance of the application of tendon transplantation decreased as a consequence of primary tendon reconstruction; however, it has remained a significant procedure in cases of secondary reconstructions. In the mirror of world literary data the author discusses the historical preliminaries of the tendon grafting, its present, modern knowledge and overviews the different reconstructive surgical procedures. Finally, he describes the present and in the future expected important conceptions: formation of a gliding system, vascularized tendon transfer, the allografts, the biomaterials and the cell-based therapies. At the end of his paper the author enclosed a plentiful literary list for the interested readers.

Keywords: $\quad$ Finger injuries - Therapy; Hand injuries - Therapy; Tendon injuries - Therapy; Tendons - Transplantation; Tissue engineering; 


\section{BEVEZETÉS}

A sérült hajlítóinak mútéti helyreállítása legeredményesebben a sérüléstől számított 8-12 órán belül elvégzett korszerü, primer ínvarrattal végezhető el, ha az ínmútét összes személyi és tárgyi feltételei fennállnak. Továbbá fontos a szakszerűen végzett, mútét utáni aktív gyógytornakezelés. Az elmúlt másfél évtizedben számos szerző előnyben részesítette a halasztott ínvarratot, amelyet a sérüléstől számított 10-14. napon végeztek el. E mútét előnye, hogy a beavatkozás programozottan, optimális személyi és tárgyi feltételek mellett hajtható végre. Az utánvizsgálatok szerint e halasztott eljárással kedvezőbb funkcionális eredmények érhetők el, mint az ügyeletben, rosszabb körülmények között ellátott eseteknél (11). Az esetek jelentős részében azonban a primer, illetve a halasztott ínvarrat nem végezhető el, mert a sebzés roncsolt, szennyezett, vagy potenciálisan fertőzött állapota, esetleg a beteg késői jelentkezése miatt. Máskor az első ellátást végző intézetben nincsenek meg a sikeres mútét elvégzéséhez szükséges személyi, tárgyi feltételek. Ilyenkor a sérült ínhoz tartozó izomzatban - általában a második héttől kezdve - az izomrostok atrofizálnak, izomkontraktúra alakul ki és az ínvarrat nem végezhető el a proximalis íncsonk megrövidülése miatt. Az ujj mozgásának helyreállítására ezekben a késői esetekben autológ, szabad íntranszplantáció elvégzését javasolja a szerzők többsége $(11,12)$.

A hajlítóín sérülések korszerű primer helyreállítása után létrejött jó végeredmények miatt az ínátültetéseket az elmúlt másfél évtizedben már csak a legsúlyosabb esetekben, másodlagos mútétként végzik (11). Ezeknél a betegeknél a károsodott, hegesen elváltozott ín körül csak kevés ép szövet található és legtöbbször nem lehetséges a csúszófelszínek helyreállítása.. Az ínátültetésekről közölt végeredmények általánosságban kedvezőtleneknek bizonyultak, csak 16-53\%-ukban találtak jó funkciót $(27,45)$. Ezen tények ismeretében a szerzők nagyobb része szükségesnek tartja a hajlítóín átültetések eredményeinek javítását és az ennek érdekében végzett experimentális, továbbá klinikai vizsgálatok további kivitelezését (79).

Fenti adatokból kitűnik, hogy a hajlítóín sérülések miatt végzett íntranszplantációk számaránya az elmúlt másfél évtizedben világszerte fokozatosan csökkent. Ami a tárgykörben megjelent publikációkat illeti, az elmúlt időszakban mégis számos közleményben foglalkoztak a témakörrel: a számunkra jelentősebbnek tartott külföldi publikációkat munkánk Irodalomjegyzékében tüntettük fel és a szöveg megfelelő részében idéztük. Dolgozatunk összeállításához bázisközleménynek, alapvető forrásmunkának elsősorban Wong és munkatársainak nemrég megjelent publikációját (79) használtuk fel. Hazai szerzők is foglalkoztak e helyreállító mútéttel: az eljárásról részben kézsebészeti monográfiákban $(43,64)$, másrészt pedig - az utóbbi évtizedre visszamenően - jelen dolgozat szerzőjétől (11-13) olvashattunk részletes adatokat. Külön kiemelendő Salamon korábbi munkássága e témakörben, aki experimentális (fény- és elektronmikroszkópos), illetve klinikai vizsgálataiban számos, alapvető megállapítást közölt az íntranszplantátumok regenerációjáról és felhasználásáról $(62,63)$.

\section{RÖVID TÖRTÉNETI HÁTTÉR}

Az extensor pollicis longus sérülésének ínátültetéssel történő pótlását Heuck, német sebész (36) végezte el 1881-ben, amely valószínűleg az első közlés volt az ínátültetésről. Ezt követte egy közlés Franciaországból, amelyben egy kutyából eltávolított ínnal pótolták a középső ujj hajlítóinát (58). A leírás szerint e beavatkozás a funkció jó visszatérését eredményezte. Lexer 1912-ben közölt eseteket (46), amelyeknél szabad íntranszplantátumokat alkalmazott; a gyógykezelésre reménytelennek látszó betegeinél ínruptura, elhanyagolt roncsolt sérülés és infekció volt a mútét előtt észlelt állapot. Leo Mayer hangsúlyozta a szilárd ín-csontrögzítés, az ép (egészséges) inak, a csúszófelszínek és az izomzat alkotta funkcionális motor jelentőségét (1916), amelyek alapját képezik a sikeres ínhelyreállításnak (51-53). Az ínátültetés technikájának tökéletesítése Sterling Bunnell (1918) nevéhez fúződik (14), aki hangsúlyozta az atraumatikus technika fontosságát, a gondos vérzéscsillapítást, az ujjak gyűrűszalag rendszerének megóvását és az aszepszist. Mayer és Ransohoff 1936-ban leírták a kétszakaszos ínrekonstrukciót (54), 
amelyben merev celloidin rudat ültettek be, hogy kialakítsanak egy pseudo-ínhüvelyt; ezt követte az ín-graft transzplantálása 4-6 héttel később. Az 1960-as évektől Bassett és Carroll már a hajlékony szilikonrudat részesítették előnyben a pseudo-ínhüvely kialakítására (7). Ezt a technikát népszerűsítette azután Hunter (1965), mint a kétszakaszos íntranszplantációs eljárást (37), amely máig is széles körben kerül alkalmazásra. E műtéti technikát főképpen a hajlítóinak rekonstrukciójára használják, azonban - kevesebb alkalommal - felhasználásra került feszítőín defektusoknál is (6).

\section{AZ ÍNTRANSZPLANTÁTUM NYERÉSE}

Napjainkig számos különböző inat alkalmaztak ínátültetés céljára. Gyakran a palmaris longus (73), a plantaris (16), a flexor digitorum superficialis (56), a fascia lata (31), az extensor digitorum longus (16) és az extensor carpi radialis longus (74) került felhasználásra. Ezek betegektől, illetve cadaverekből kerültek eltávolításra (16). Nyelezett ínplasztikát is felhasználtak ínátültetés céljaira: a flexor digitorum profundus és a flexor superficialis proximalis csonkjait, a tenyérben összevarrva használták fel az inakat, kétszakaszos mútét során íntranszplantátumként (57).

Kutatásokat végeztek az intrasynovialis inak ín-graftként történő felhasználására is. Ezek az inak külső felszínükön epithelialis réteggel (epitenonnal) rendelkeznek, amely kompakt, sima felszínt képez és elősegíti az elcsúszási folyamatot (72). Az intrasynovialis ín ezen felül jól körülírt intravascularis rendszerrel rendelkezik, terminális ér-kacsokkal, amelyek lezárják a területet a viszonylagosan érszegény ínrészektől (67). In vitro tanulmányok kimutatták, hogy a kollagénszintézis alacsonyabb fokú az intrasynovialis inaknál, mint az extrasynovialisoknál (1). Hasonlóképpen különbség mutatkozott a növekedési faktor stimuláció érzékenységében a két ínfajta között (3). További vizsgálatokból kiderült, hogy az extrasynovialis ín proliferációs képessége és aktív szintetizáló hajlama jóval nagyobb fokú, mint az intrasynovialis íné; mindez azt sugallja, hogy az utóbbi biológiailag kevésbé aktív és jobban alkalmazkodik a synovialis környezethez (2). Az ínátültetés után kisebb fokú ínkörüli összenövések alakulnak ki, ezért tartják ezt az ínfajtát alkalmasabbnak transzplantáció céljára.

\section{AZ ÍN-GRAFT GYÓGYULÁSI FOLYAMATÁNAK ALAPJAI}

Régebbi elméletek szerint az ín gyógyulási folyamata extrinsic és intrinsic formákra osztható fel. Ennek megfelelően az ín gyógyulhat a környező szövetekből származó fibroblastok proliferációja útján (extrinsic gyógyulás), vagy a vérellátástól kevésbé függően a synovialis folyadék diffúziós táplálása révén (intrinsic gyógyulás). Szövettani vizsgálatokkal kimutatták, hogy az ínhüvely és a subcutan szövetek gyorsabban gyógyulnak, mint az íntranszplantátum (49). Patkánykísérletekben, profundus ín autograftokon végzett, izotóppal jelölt thymidin vizsgálatokban észlelték, hogy az ínátültetés első 48 órájában a sejtek fokozatos migrációja figyelhető meg a környező szövetek felé; ez a proliferáció a tetőpontját az első 24 órában éri el; amely az ínvégeken a 6. napra fejlődik ki (47).

Korábban alapelvnek tekintették, hogy az ínkörüli összenövések szükséges részei az ín gyógyulásának, amelyeken keresztül létrejött extrinsic vérellátás biztosítja a graft gyógyulását (59). Azonban nyúl flexor inain végzett kísérletekben, ahol az inakat részlegesen bemetszették az ínhüvelyen kívül, majd viszszahelyezték az ép ínhüvelybe, igazolódott, hogy a hajlítóínnak nincs feltétlenül szüksége a gyógyuláshoz a külső vérellátás kialakulására. Az íntranszplantátum gyógyulhat adhaesiók nélkül is, és ilyenkor a táplálását a környező intrasynovialis folyadékból kapja (50). Manske és munkatársai 1979-ben kimutatták (48) radio-izotóp prolinnal végzett vizsgálataikban, hogy a fent említett folyadék a synovialis hüvelyt körülvevő mikrokapillárisok ultrafiltrátuma. Más szerzők is kimutatták, hogy az intrasynialisan sérült ín képes volt vascularis összenövésektől függetlenül gyógyulni a synovialis környezetben (35). Ezek a kísérletek bátorítottak egyes kutatókat az intrinsic gyógyulás fogalomkörének elfogadására. Mások kétségüket fejezték ki az elmélettel szemben, mivel irradiációval, vagy liofilizálással kezelt íntranszplantátumok szintén öszszenövésektől mentesen gyógyultak synovialis 
környezetben, azt a lehetőséget sugallva, hogy az érintett sejtek bárhonnan vándorolhatnak az ínba $(20,60)$.

$\mathrm{Az}$ íngyógyulással foglalkozó, újabb irodalmi adatok levezethetők Singer és Clark sebgyógyulási elméletéből, megértendő a graft gyógyulási mechanizmusát (68). A gyógyulás során a friss plazma alvadékok ideiglenes sejtközi állományból összetevődő vázat formálnak, ahová az ínból származó fibroblastok vándorolnak, és új kollagént szintetizálnak (9). Ezeknek a sejteknek a vándorlása rendszerint 48 órán belül fejlődik ki és e migrációt befolyásolják különböző mátrix összetevők: fibrinogén, thrombin, fibronectin, hyaluronsav és proteoglycánok (32). A fibrin és a fibronectin kulcs mátrix molekulák, amelyek meggyorsítják a sejtek összekapcsolódását, vándorlását, a kollagén sejtmagok kialakulását (ez az első lépése a kollagénforma kialakulásához) és a kollagén rostok összetömörülését egy új ínszövethez, vagy az összenövések kialakulásához (15). Az ideiglenes mátrix felhalmozódás az íntranszplantátum körül fontos tényező, amikor a graft ép ínhüvelyben, vagy ál-ínhüvelyben (pseudosheath) helyezkedik el, amely mérsékelni fogja az ínkörüli összenövéseket. Amenynyiben ínhüvely nem létezik, a peritendinosus szövetek olyan sejtekkel fognak telítődni, amelyek az ínszövetet infiltrálva hasonlatossá teszik a szubkután szövetekben találhatókhoz, és ily módon alakulnak ki az ínkörüli összenövések (78). A synovialis sejteket tartalmazó ínhüvely (fibro-ossealis csatorna) a környező, szubkután szöveteket kívül tartja, és nem engedi kontaktusba kerülni a benne lévő grafttal, mechanikus gátat képezve az infiltráló sejtekkel szemben. $\mathrm{Az}$ ínhelyreállítás helyén megfigyelték az endothelialis, a csontvelőből származó sejtek és a synovialis fibroblastok vándorlását is (39).

Kísérletes munkákban igazolták, hogy az intrasynovialis inak esetében 65\%-ban, míg az extrasynovialis inaknál 25\%-ban az ínsejtek túléltek (1). Ez azt sugallja, hogy az intrasynovialis inak lényegesen alkalmasabbak transzplantáció céljára (4). A különbség a sejtek túlélésében azt mutatja, hogy az intrasynovialis inak sejtjei az ischaemiával szemben jobb tűrőképességgel rendelkeznek, és alacsonyabb anyagcsereigényük van, mint az extrasynovialis inaknak (76).

$\mathrm{Az}$ ínátültetések után tinta-injiciálási technikát alkalmazva kimutatták, hogy a revaszkularizáció feltétlenül szükséges az íngraft túlélése szempontjából. Az extrasynovialis graftok revaszkularizációja a 2 . héten fejlődik ki az összenövésekben futó erek révén. Ugyanakkor intrasynovialis inaknál az inakban futó erek proliferációja az elsődleges forrása a vérellátásnak és az ínfelszín újraereződése kisebb szerepet játszik (30). Potenza kevés, vagy egyáltalán semmiféle sejtelhalást nem látott, amikor intrasynovialis inat ültetett át (59), míg Flynn és munkatársai nagyfokú acellularis nekrózist találtak extrasynovialis ínátültetésnél (26).

A gyógyulás inflammációs fázisa után, a kollagénszintézis és a sejt proliferáció fokozatos növekedést mutat az íntranszplantátumban. A sejtek apoptózisa (sejthalál) részét képezi a sejtek újonnan képződési ciklusának. A graftban lévő új (donor) sejtek mellett az első héten fokozatosan csökken az eredeti sejtszám 20\%-ra és 4 hét után már nem találhatók a transzplantátumban régi sejtek (5). Az összes sejt kicserélődése a graftban függ a transzplantátum nagyságától, és hónapokat vehet igénybe. A repopuláció ideje változó és számos tényezőtől függ: a tanulmányozott ín eredetétől, az ín helyétől, illetve az ín méretétől (79).

Számos tanulmány kimutatta, hogy az ínrekonstrukció utáni korai mobilizáció, ennél fogva a graft feszülés alá kerülése jó funkcionális végeredményhez vezethet (69). A tenocyták szintetizálják a kollagént, erősebb kollagén rostokat hoznak létre a fiziológiai feszülés hatására és e sejtek szintén védettek az apoptózis ellen (23). A graft mozgása a fibro-ossealis csatornában szintén meghiúsítja körülötte az ideiglenes alvadék kialakulását, amely összenövések kialakulását idézi elő (78).

$\mathrm{Az}$ ínátültetés során génexpressziót vizsgáló tanulmányok a gének szabályozását mutatták az első pár napban (40). Ezt követte a növekedési faktor expressziója, majd a kollagén és a mátrix gének tömeges aktiválása, új szövetféleség létrehozása érdekében. Mátrix metalloproteinase gének szintén aktiválódtak, amelyek szintén szerepet játszanak a mátrix komponensek remodellezésében. Az inak feszülésének növekedését találták az MMP2 és Col3a1 gének expressziója esetében a gyógyulás első hetében (66). Ez hasonlóképpen erősebb inak létrejöttéhez vezetett. A graft kiérése során fokozatos növekedés volt megfigyelhető 
a progenitor és a differentálódásért felelős gének expressziójában. A kölcsönhatás megerősítése a tárgyalt gének és az új mátrix kialakulása között a folyamatban lévő kutatások fontos részét képezik (79).

\section{A graft proximalis és distalis varrata}

A graft proximalis részének befonási technikája Pulvertaft nevéhez füződik (61) és máig is az egyik legnépszerűbb és legszilárdabb rögzítést biztosító módszernek bizonyult. Az eljárás alternativájaként szóba jön az úgynevezett lasszó, vagy kacs eljárás (10), továbbá a spirális rögzítési, (44) illetve az úgynevezett vég-befonási technika (28). Mindezek az eljárások egyszerúbb megoldást kínálnak a Pulvertaft-féle varrattal szemben, de összességében gyengébb szakítószilárdsággal rendelkeznek. A laboratóriumi vizsgálatok szerint a befonásos módszerek feltűnően szilárdabbnak bizonyultak, mint a szabványos, négy, intratendinealis öltésből álló ínvarratok (10).

Számos eljárást írtak le az ín distalis részének rögzítésére. Ezeket a következő módon osztályozták: ín az ínhoz, ín a csonthoz, ín a csonton (furattal) keresztül és rögzítés a csont körül (77). Tanulmányokban kimutatták, hogy az a rögzítési módszer, amikor a distalis transzplantátum-rész rögzítését csont csatornán belül végezték, lényegesen erősebb rögzítést biztosít, mint abban az esetben, ha az ín fixálása a csont külső felszínére történt (22).

\section{Az álínhüvely kialakítása}

$A z$ ínhüvely sérülésének eseteiben szükség lehet szilikonrúd körül kialakított, úgynevezett álínhüvely képzésére. Főemlősökön végzett kísérletekben kimutatták, hogy a Hunter-féle szilikonrúd körül létrejött pseudosynovialis hüvelyt három, jól elhatárolt réteg alkotja: az intima, a media és az adventitia, hasonlóan az ép ínhüvely fibrózus csatornájához (38). $\mathrm{Az}$ intima rétege glycosaminoglycanokat tartalmaz, és szekréciós kapacitással rendelkezik. A mediában nagy mennyiségú kollagént és véredényeket találunk, az adventitia vérereket és laza, fibrózus szövetelemeket tartalmaz (25). Ultrastrukturális vizsgálatok hasonló morfológiával rendelkező, A és B típusú sejteket mutattak ki az ízületi synoviumban is. Az irodalomban általánosan elfogadott, hogy súlyos sérülés esetében ajánlatos elvégezni a kétszakaszos ínhelyreállító mútétet: kialakítani az új, fibro-ossealis ínhüvelyt és a csúszófelszíneket, amelyet később az íntranszplantátum beültetése követ. Mindazonáltal, egy tanulmányban összehasonlításra került az egyszakaszos ínátültetés a kétszakaszos, szilikonrúddal végzett eljárással és nem találtak lényeges különbséget a két csoport között az ujjak teljes, aktív mozgása (TAM) és az ujjbegy - palmaris redő közötti távolság nagyságában (75). Mindezek ellenére a megjósolható kedvező eredmények miatt a szerzők többsége általánosságban javasolja súlyos esetekben a kétszakaszos mútét elvégzését (70).

\section{A fejlődés föbb irányvonalai}

Az íngraft körül kialakuló összenövések kérdése alapvetően egyet jelent az ínfelszín kezelésével. Mivel az intrasynovialis donor ínfelszín kedvezőbb tulajdonságokat mutat, az extrasynovialis inakat carbodiimiddel derivált hyaluron-savval kezelték ( $c d-H A)$; ennek alkalmazása csökkentette az összenövések kialakulását a graftok körül (42). A felszín tulajdonságainak megváltoztatása lubricinnel, amely a synovialis folyadék alapvető síkosító anyaga, szintén ígéretes, fejlesztés alatt álló kezelési eljárásnak tûnik (71). Egy másik újabb kísérletes kutatási irányzat a funkcionális synovialis membrán kifejlesztése az extrasynovialis inak felszínén, amely stimuláló hatást gyakorol a synoviocitákra, hogy synoviolin-t termeljenek (18).

Mikrosebészeti technikával végzett ínrekonstrukciót javasolt több szerző az ínátültetéseknél: vérellátással rendelkező ínáthelyezést (55), illetve a teljes csúszófelszínnel rendelkező, érnyeles íntranszpozíciót (33). Az utóbbi elgondolás felkínálja az ujj mozgásának megmentési lehetőségét komplex sérülés esetén, és lehetővé teszi az egyidejü bőrpótlást, valamint a lágyrészek fedését, beleértve az inat és az ínhüvelyt is. Ez a mútéti technika azonban függ az ulnaris artéria épségétől, és magába foglalja az arteria ulnaris ellátó területének feláldozását, annak érdekében, hogy ennek a retrográd lebenynek a vérellátását biztosítsa; mindez azonban a felhasználhatóságát korlátozza (17). A teljes csúszófelszín áthelyezése, vaskularizált, összetett transzplantátumként 
nem igényel immunoszuppressziós kezelést és ez nem vitatható előnyére írandó az eljárásnak, azonban az e mútétet igénylő sérülések ritkák $(11,34)$.

A szövetépités (tissue engineering) számos módszere áll fejlesztés alatt, hogy a test saját helyreállító és regenerációs folyamatai révén hozzanak létre a sebzés területén ínszövetet (13). Ez jelenthet vagy túlnyomóan sejtalapú, vagy egy vázon létrehozott eljárásokat, illetve a kettő kombinációját (29). Az ínsejtek viszonylag homogén szerkezetűek, és amikor tenocytákat tenyésztenek szövetkultúrában, azok a folyamat során spontán összeállnak háromdimenziós, ínszövetre hasonlító szerkezetté (24). Egyes kísérletes vizsgálatokban kimutatták, hogy az ínszövetben található, illetve a bőrben lévő fibroblastok és a mesenchymalis őssejtek mindannyian képesek önmaguktól kollagénné összeállni és ilyen módon létrehozni ínszövethez hasonlító struktúrát (41). Csupán kevés tanulmányban alkalmazták e módszert, hogy mü-inat hozzanak létre ínátültetés céljából. Mindazonáltal több szerző $(65,79)$ azt találta, hogy e módszernél az ínszövet rosszabb mechanikai tulajdonságai, korlátozott átmérője és a hosszú előállítási ideje - amely szükséges a graft kiéréséhez - megnehezíti olyan autológ szövet kifejlesztését, amely jelenleg alkalmassá teheti a humán felhasználás céljaira.

Alternatív megoldásként szóba jöhetnek, egyes anyagok, amelyek elméletileg képesek azonnali mechanikai szakítószilárdságot biztosítani. Ezeket évtizedek óta használják ínpótlás céljaira. Az eredeti, Hunter-féle (37) elképzelést Brunelli dolgozta ki szilikonnal bevont polyamid ín-implantátumot használva, amelyet distalisan titanium lemezzel erősített a végperchez (8). Ma még nehéz kijelenteni, hogy e biológiai anyagok valóban nyújtanak-e ínhelyettesítő eljárást (21). Azonban, hasznos választás lehet az ínátültetéseknél használt hagyományos eljárásokhoz képest és szélesebb körű használata a jövőben elképzelhető lesz.

Decellularizált, cadaverből nyert inak lehetséges graft-forrásként szerepelhetnek, átépülhetnek autológ sejtekké, és úgy túnik, hogy hasonló szakító szilárdságúak, mint az autograftok (19). E transzplantátumok kivétele, és tárolása egyszerúbb, a mútét időtartama is csökken, emellett jelentős költségkímélő hatása is van (79).

Nehéz megjósolni, hogy a fent vázolt kísérletes eredmények hogyan fogják átalakítani az ínsebészetben alkalmazott mútéti eljárások fejlődését és mindez hogyan fog hatni az íntranszplantáció eredményességére. Mindenesetre számos - a dolgozatban ismertetett - biológiai kérdést szükséges még megválaszolni ahhoz, hogy idővel a jelenleginél jobb funkcionális végeredményeket érhessünk el egy eredményesebben alkalmazható ín-graft kifejlesztésével. Ez a talán a nem is olyan távoli jövő feladatát fogja képezni. 


\section{IRODALOM}

1. Abrahamsson S. O., Gelberman R. H., Lohmander S. L.: Varations in cellular proliferation and matrix synthesis in intrasynovial and extrasynovial tendons: an in vitro study in dogs. J. Hand Surg. Am. 1994. 19: 259-265.

2. Abrahamsson S. O., Gelberman R. H., Amiel D., Winterton P., Harwood F.: Autogenous flexor tendon grafts: fibroblast activity and matrix remodeling in dogs. J. Orthop. Res. 1995. 13: 58-66.

3. Abrahamsson S. O., Lohmander S.: Differential effects of insulin-like growth factor-I on matrix and DNA synthesis in various regions and types of rabbit tendons. J. Orthop. Res. 1996. 14: 370-370.

4. Ark J. W., Gelberman R. H., Abrahamsson S. O., Seiler J. D., Amiel D.: Cellular survival and proliferation in autogenous flexor tendon grafts. J. Hand Surg. Am. 1994. 19: 249-258.

5. Alam N., McGrouther D. A., Wong J. K.: The cellular biology of tendon grafting. J. Hand Surg. Eur. 2014. 39: 79-92.

6. Al-Qattan N. M.: Two-staged extensor tendon reconstruction for zone 6 extensor tendon loss of the fingers: indications, technique and results. J. Hand Surg. Eur. 2015. 40: 276-280.

7. Bassett C. A. L., Carroll R. E.: Formation of tendon sheaths by silicone rod implants. J. Bone Joint Surg. Am. 1963. 45: 884885.

8. Battiston B., Triolo P. F., Bernardi AQ., Artiaco S., Tos P.: Secondary repair of flexor tendon injuries. Injury. 2013. 44: 340-345.

9. Becker H., Graham M. F., Cohen I. K., Diegelmann R. F.: Intrinsic cell proliferation in tissue culture. J. Hand Surg. Am. 1981. 6: 616-619.

10. Bidic S. M., Varshney A., Ruff M. D., Orenstein H. H.: Biomechanical comparison of lasso9, Pulvertaft weave, and side-byside tendon repairs. Plast. Reconstr.Surg. 2009. 124: 567-571.

11. Bíró V.: Az ínátültetés helye és szerepe a kéz hajlitóín sérüléseinek helyreállitásában. Történeti áttekintés és az irodalmi adatok elemzö értékelése. Magyar Traumatológia Ortopédia Kézsebészet Plasztikai Sebészet. 2008. 51. (1): 57-66.

12. Bíró V.: Hajlítóín sebészet - a kézsebészet egyik fontos részterületének fejlödése. (Felkért közlemény). Orv. Hetil. 2012. 153(21): 811-820.

13. Bíró V.: Szövetépítés lehetőségei a kéz hajlítóín sérüléseinek helyreállításában. Orv. Hetil. 2015. 156. (6): 216-220. DOI 10. 1556/OH.2015.300094

14. Bunnell S.: Repair of tendons in the fingers and description of two new instruments. Surg. Gynecol. Obstet. 1918. 26: 103110.

15. Canty E. G.., Kadler K. E.: Collagen fibril biosynthesis in tendon: a review and recent insights. Comp. Biochem. Physiol. A. Mol. Integr. Physiol. 2002. 133: 979-985.

16. Carlson G. D., Botte M. J., Josephs M. S., Newton P. O., Davis J. L., Woo S. L.: Morphologic and biomechanical comparison of tendons tendons used as free grafts. J. Hand Surg. Am. 1993. 18: 76-82.

17. Cavadas P. C., Garca A., Thione A., Lorca-Garcia C.: Single-stage reconstruction of flexor tendons with vascularized tendon transfers. J. Hand Surg. Eur. 2015. 40: 259-268.

18. Chen T. G., Zhang S. X., Tao Z. F. et al.: Overexpression of synoviolin facilitates the formation of a functional synovial biomembrane. J. Biomed. Mater. Res. A. 2012. 100: 1761-1769.

19. Chong A. K., Riboh J., Smith R. L., Lindsey D. P., Pham H. M., Chang J.: Flexor tendon tissue engineering acellularized and reseeded tendon construct. Plast. Reconstr. Surg. 2009. 123: 1759-1766.

20. Chow S. P., Hooper G., Chan C. W.: The healing of freeze-dried rabbit tendon in a synovial fluid environment. Hand. 1983. 15: 136-142.

21. Czaplewski S. K., Tsai T. L., Duenwald-Kuehl S. E., Vanderby R., Li W. J.: Tenogenic differentation of human induced pluripotent stem cell-derived mesenchymal stem cells dictated by properties of braided submicron fibrous scaffolds. Biomaterials. 2014. 35: 6907-6917.

22. Dovan T. T., Ritty T., Ditsios K., Silva M. J., Kusano N., Gelberman R. H.: Flexor digitorum profundus tendon to bone tunnel repair: a vascularization and histologic study in canines. J. Hand Surg. Am. 2005. 30: 246-257.

23. Egerbacher M., Arnoczky S. P., Caballero O., Lavagnino M., Silva M. J.: Loss of homeostatic tension induces apoptosis in tendon cells: an in vitro study. Clin. Orthop. Relat. Res. 2008. 466: 1562-1568.

24. Evans C. E., Trail I. A.: Fibroblast-like cells from tendons differ from skin fibroblasts in vitro. J. Hand Surg. Br. 1998. 23: 633-641.

25. Farkas L. G., McCain W. G., Sweeney P., Wilson W., Hurst L. N., Lindsay W. K.: An experimental study of the changes following silastic rod preparation of a new tendon sheath and subsequent tendon grafting. J. Bone Joint Surg. Am. 1973. 55: 1149-1158.

26. Flynn J. E., Wilson J. T., Child C. G., Graham J. H.: Heterogenous and autogenous-tendon transplants. An experimental study of preserved bovine-tendon transplants in dogs and autogenous-tendon transplants in dogs. J. Bone Joint Surg. Am. 1960. 42: 91-110.

27. Frakking T. G., Depuydt K. P., Kon M., Werker P. M.: Retrospective outcome analysis of staged flexor tendon reconstruction. J. Hand Surg. Br. 2000. 25: 168-174.

28. Gabuzda G. M., Lovallo J. L., Nowak M. D.: Tensile strength of the end-weave flexor tendon repair. An in vitro biomechanical study. J. Hand Surg. Br. 1994. 19: 397-400.

29. Galvez M. G., Crowe C., Farnebo S., Chang J.: Tissue engineering in flexor tendon surgery: current state and future advances. J. Hand Surg. Eur. 2014. 39: 71-78. 
30. Gelberman R. H., Seiler J. G., Rosenberg A. E., Heyman P., Amiel D.: Intercalary flexor tendon grafts. A morphological study of intrasynovial and extrasynovial donor tendons. Scand. J. Plast. Reconstr. Surg. 1992. 26: 257-264.

31. Goubier J., Teboul F.: Restoration of active fingers flexion with tensor fascia lata transfer in total brachial plexus palsy. Tech. Hand Up. Extrem. Surg. 2009.13: 1-3.

32. Graham M. F., Becker H., Cohen I. K., Merritt W., Diegelmann R. F.: Intrinsic tendon fibroplasia: documentation by in vitro studies. J. Orthop. Res. 1984. 1: 251-256.

33. Guimberteau J. C., Panconi B., Boileau R.: Mesovascularized island flexor tendon: new concepts and techniques for flexor tendon salvage surgery. Plast. Reconstr. Surg. 1993. 92: 888-903.

34. Guimberteau J. C., Bakhach J. Panconi B., Rouzaud S.: A fresh look at vascularized flexor tendon transfers: concept, technical aspects and results. J. Plastic. Reconstr. Aesthet. Surg. 2007. 60: 793-810.

35. Hansson H. A., Lundborg G., Rydevik B.: Restoration of superficially damaged flexor tendons in synovial environment. An experimental ultrastructural study in rabbits. Scand. J. Plast. Reconstr. Surg. 1980. 14: 109-114.

36. Heuck G.: Ein Beitrag zur Sehnenplastik. Zentralbl. Chir. 1881. 9: 289-292.

37. Hunter J.: Artificial tendons. Early development and application. Am. J. Surg. 1965. 109: 325-338.

38. Hunter J. M., Jaeger S. H., Matsui T., Miyaji N.: The pseudosynovial sheath -its characteristic in a primate model. J. Hand Surg. Am. 1983. 8: 461-470.

39. Iwata Y., Morihara T., Tachiiri H., Kajikawa Y., Yoshida A., Arai Y., Tokunaga D., Sakamoto H., Matsuda K., Kurokawa M., Kawata M., Kubo T.: Behavior of host and graft cells in the early remodeling process of rotator cuff defects in a transgenic animal model. J. Shoulder Elbow Surg. 2008. 17: 101S-107S.

40. Juneja S. C., Schwarz E. M., O'Keefe R. J., Awad H. A.: Cellular and molecular factors in flexor tendon repair and adhesions: a histological and gene expression analysis. Connect. Tissue Res. 2013. 54: 218-226.

41. Kapacee Z., Yeung C. Y., Lu Y., Crabtree D., Holmes D. F., Kadler K. E.: Synthesis of embryonic tendon-like tissue by human marrow stroma/mesenchymal stem cells requires a three-dimensional environment and transforming growth factor beta3. Matrix Biol. 2010. 29: 668-677.

42. Karabekmez F. E., Zhao C.: Surface treatment of flexor tendon autograft and allograft decreases adhesion without an effect of graft cellularity: a pilot study. Clin. Orthop. Relat. Res. 2012. 470: 2522-2527.

43. Kós R.: A kéz sebészete. Budapest. Medicina. 1961. 141-145. p.

44. Kulikov Y. I., Gheduzzi S., Miles A. W., Giddins G. E.: An in vitro biomechanical study comparing the spiral linking technique against the Pulvertaft weave for tendon repair. J. Hand Surg. Eur. 2007. 32: 377-381.

45. LaSalle W. B., Strickland J. W.: An evaluation of the two stage flexor tendon reconstruction technique. J. Hand Surg. Am. 1983. 8: 263-267.

46. Lexer E.: Die Verwertung der freien Sehnentransplantation . Langenbecks Arch. Klin. Chir. 1912. 98: 818-852.

47. Lindsay W. K., Birch J. R.: The fibroblast in flexor tendon healing. Plast. Reconstr. Surg. 1964. 34: 223-232.

48. Manske P. R., Lesker P. A., Bridwell K.: Experimental studies in chickens on the initial nutrition of tendon grafts. J. Hand Surg. Am. 1979. 4: 565-575.

49. Mason M. L., Shearon C. G.: The process of tendon repair: an experimental study of tendon suture and tendon graft. Arch. Surg. 1932. 25: 615-692.

50. Matthews P., Richards H.: The repair reaction of flexor tendon within the digital sheath. Hand. 1975. 7: 27-29.

51. Mayer L.: The physiological method of tendon transplantation. I. Historical, anatomy and physiology of tendons. Surg. Gynecol. Obstet. 1916. 22: 182-197.

52. Mayer L.: The physiological method of tendon transplantation. II. Operative technique. Surg. Gynecol. Obstet. 1916. 22: 298-306.

53. Mayer L.: The physiological method of tendon transplantation. III. Experimental and clinical experiences. Surg. Gynecol. Obstet. 1916. 22: 472-481.

54. Mayer L., Ransohoff N.: Reconstruction of the digital tendon sheath: a contribution to the physiological method repair of damaged finger tendon. J. Bone Joint Surg. Am. 1936. 18: 607-616.

55. Morrison W. A., Cleland H.:Vascularised flexor tendon grafts. Ann. Acad. Med. Singapore. 1995. 24: $26-31$.

56. Naam N. H.: Staged flexor tendon reconstruction using pedicled tendon graft from the flexor digitorum superficialis. J. Hand Surg. Am. 1997. 22: 323-327.

57. Paneva-Holevich E.: Two stage tenoplasty in injury of the flexor tendons of the hand. J. Bone Joint Surg. Am. 1969. 51: 21-32.

58. Peyrot J. J.: Transplantation chez I'homme un tendon emprunt un chien. Guerison avec. rees- tablissement partiel de la function. Bull. Mem. Soc. Chir. Paris. 1886. 12: 356-361.

59. Potenza A. D.: The healing of autogenous tendon grafts within the flexor digital sheath in dogs. J. Bone Joint Surg. Am. 1964. 46: 1462-1484.

60. Potenza A., Herte M. C.: The synovial cavity as a "tissue culture in situ" - science or nonsense? J. Hand Surg. Am. 1982. 7: 196-199.

61. Pulvertaft R. G.: Tendon grafts for flexor tendon injuries in the fingers and thumb; a study of technique and results. J. Bone Joint Surg. 1956. 38: 175-194.

62. Salamon A.: Az intranszplantátumok funkcionális alkalmazkodása a kollagén újdonképződés strukturális változásának függvényében. Doktori Értekezés. Szombathely. 1979. 
63. Salamon A: Az íntranszplantáció indikációja és módszerei. Kézsebészeti Kerekasztal konferencia. Szeged, 1980: 31-36.

64. Sántha E.: A hajlitóinak sérülései és betegségei. In: Renner A., Sántha E.: A kéz sebészete. Budapest. Kadix Press. 2014. 233-242. $p$.

65. Sawadkar P., Alexander S., Mudera V.: Tissue-engineered collagen grafts to treat large tendon defects. Regen. Med. 2014. 9: 249-251.

66. Scott A., Sampaio A., Abraham T., Duronio C., Underhitt T. M.: Scleraxis expression is coordinately regulated in a murine model of patellar injury. J. Orthop. Res. 2011. 29: 289-296.

67. Shin R. H., Zhao C., Zobitz M. E., Amadio P. C., An K. N.: Mechanical properties of intrasynovial and extrasynovial tendon fascicles. Clin. Biomech. 2008. 23: 236-241.

68. Singer A. J., Clark R. A.: Cutaneous wound healing. N. Engl. J. Med.1999. 341: 738-746.

69. Smith P., Jones M., Grobbelaar A.: Two-stage grafting of flexor tendons: results after mobilization by controlled early active movement. Scand. J. Plast. Reconstr. Surg. Hand Surg. 2004. 38: 220-227.

70. Sun S., Ding Y., Ma B., Zhou Y.: Two-stage flexor tendon reconstruction in zone II using Hunter's technique. Orthopedics. 2010. 33: 880 .

71. Taguchi M., Sun Y. L., Zhao C., Zobitz M. E., Cha C. J., Jay G. D., An K. N., Amadio P. C.: Lubricin surface modification improves extrasynovial tendon gliding in a canine model in vitro. J. Bone Joint Surg. Am. 2008. 90: 129-135.

72. Taylor S. H., Al-Youha S., Van Agtmael T., Lu Y., Wong J., McGrouther D. A., Kadler K. E.: Tendon is covered by a basement membrane epithelium that is required for cell retention and the prevention of adhesion formation. PLoS One. 2011. 6: e16337.

73. Tolat A. R., Stanley J. K.: The extended palmaris longus tendon graft. J. Hand Surg. Br. 1993. 18: 239-240.

74. Vergara Amador E.: New flexor tendon graft of fingers using the extensor carpus radialis longus. Anatomical and clinical study. Acta Orthop. Mex. 2010. 24: 66-69.

75. Weeks P. M., Wray R. C.: Rate and extent of functional recovery after flexor tendon grafting with and without silicone rod preparation. J. Hand Surg. Am. 1976. 1: 174-180.

76. Wiig M., Abrahamsson S. O.: Hyaluronic acid modulates cell proliferation unequally in intrasynovial and extrasynovial rabbit tendons in vitro. J. Hand Surg. Br. 2000. 25: 183-187.

77. Wilson S., Sammut D.: Flexor tendon graft attachment: a review of methods and a newly modified tendon graft attachment. J. Hand Surg. Br. 2003. 28: 116-120.

78. Wong J. K., Lui Y. H., Kapacee Z., Kadler K. E., Ferguson M. W., McGrouther D. A.: The cellular biology of flexor tendon adhesion formation: an old problem in a new paradigm. Am J. Pathol. 2009. 175: 1938-1951.

79. Wong R., Alam N., McGrouther A. D., Wong J. K. F.: Tendon grafts: their natural history, biology and future development. J. Hand Surg. Eur. Vol. 2015. 40E. (7): 669-681. DOI: 10.1177/17531193415595176

\section{Prof. Dr. Bíró Vilmos}

7633 Pécs, Hajnóczy u. 25/a, II. em. 2.

E-mail: biro.vilmos2@chello.hu 